\title{
O WARTOŚCI INFORMACYJNEJ TESTÓW PRZYCZYNOWOŚCI W SENSIE GRANGERA
}

\begin{abstract}
Streszczenie
Celem artykułu jest wykazanie na podstawie przeglądu badań, że zastosowanie testów Granger-przyczynowości nie dostarcza wiarygodnych informacji o zależności pomiędzy badanymi szeregami czasowymi, jeżeli nie dysponuje się wiedzą teoretyczną na ich temat. Dotychczasowa krytyka testowania przyczynowości w sensie Grangera skupiała się przede wszystkim na wskazywaniu różnic pomiędzy tradycyjnie rozumianą przyczynowością a definicją zaproponowana przez Grangera. Autor wykazuje, że analizowana definicja przyczynowości ma uzasadnienie filozoficzne, jednak stosowanie testów Granger-przyczynowości prowadzi do błędnych wniosków, co jest wynikiem m.in.: nieliniowości szeregów czasowych, zbyt rzadkiego próbkowania szeregów czasowych, skointegrowania zmiennych, zdeterminowania szeregów czasowych przez trzecią zmienna, istnienia zależności nieliniowej oraz racjonalnych oczekiwań podmiotów ekonomicznych. Analiza opisanych w literaturze przypadków zawodności wyników testów przyczynowości w sensie Grangera pozwala stwierdzić, że wyciagnięcie wniosków o istnieniu i kierunku zależności przyczynowej na podstawie testu Granger-przyczynowości jest możliwe tylko wtedy, gdy posiada się wiedzę o mechanizmie łączącym dwa szeregi czasowe.
\end{abstract}

Słowa kluczowe: przyczynowość w sensie Grangera, testowanie przyczynowości, przyczynowość w ekonomii

\section{ON INFORMATIVENESS OF GRANGER-CAUSALITY TESTS}

\section{Summary}

The purpose of this paper is to show that the application of Granger-causality tests is not informative unless one possesses additional theoretical knowledge. Previous criticism on Granger-causality testing pointed out mostly the differences between the common sense understanding of causality and Granger's definition. The author demonstrates that Granger's definition of causality is philosophically justified. However, the use of its tests is misleading due to: data non-linearity, too low sampling rate, time series cointegration, thirdvariable fallacy, non-linear causal dependency, and the rational expectations of economic agents. It can be said that the fallibility of Granger-causality testing described in the literature makes drawing conclusions about the existence and direction of causal relationship possible only if the researcher applying a Grangercausality test has knowledge of the mechanism connecting the two time series.

Key words: Granger-causality, causality testing, causality in economics

DOI: $10.15290 /$ ose.2015.02.74.10

\footnotetext{
${ }^{1}$ Mgr Mariusz Maziarz - Szkoła Główna Handlowa; e-mail: mm46256@sgh.waw.pl.
} 


\section{Wstęp}

Rosnąca popularność jednej z metod empirycznego testowania istnienia zależności przyczynowych bez odwoływania się do mechanizmów, tj. przyczynowości w sensie Grangera (ang. Granger-causality) powoduje, że nie można zgodzić się ze zdaniem LeRoy'a [LeRoy, 2004], że temat przyczynowości przeminął jako obszar interesujący ekonomistów. Najprostszą definicja przyczynowości Grangera, zaproponowana przez autora [Granger, 1980], jest stwierdzenie, że zmienna A powoduje B, jeśli prawdopodobieństwo warunkowe $B$, wziąwszy pod uwagę historię: jej własną i zmiennej A, nie równa się prawdopodobieństwu warunkowemu B na podstawie wyłącznie jej własnej historii.

Hoover [Hoover, 2006] określa Granger-przyczynowość jako najbardziej wpływowe podejście do przyczynowości w ekonomii. Opisywana w artykule metoda badania istnienia zależności przyczynowej pomiędzy zmiennymi stochastycznymi została wprowadzona przez Grangera [Granger, 1969], spotykając się z ostrą krytyką, skoncentrowana głównie na różnicy pomiędzy Granger-przyczynowością a rozumieniem pojęcia przyczynowości w tradycyjny sposób [Liu, Bahadori, 2012] oraz na pewnych aspektach metodologicznych i błędach wynikających z jej aplikacji do problemów empirycznych. W dotychczasowych badaniach podkreślano jedynie niektóre błędy [Russo, 2008], do których może prowadzić zastosowanie Granger-przyczynowości, nie rozważając, jakie prawomocne wnioski można wyciagnać stosując tę metodę. Celem artykułu jest wykazanie, że wyniki testu Granger-przyczynowości są niekonkluzywne, ponieważ nie pozwalają na sformułowanie wniosków na temat zależności pomiędzy analizowanymi szeregami czasowymi bez odwoływania się do wiedzy o opisujących je mechanizmach.

Istotę badań nad interpretacją wyników testów Granger-przyczynowości podkreśla popularność tej metody w badaniach naukowych (por.: rozdział 2.) oraz poważanie, jakim się cieszy. Rozdział 3. zawiera opis definicji przyczynowości zaproponowanej przez Grangera oraz wskazuje filozoficzne inspiracje autora. Główna część artykułu (rozdział 4.) jest analizą zjawisk prowadzących do niepoprawnych wyników testów Granger-przyczynowości. We wnioskach przedstawiono niekonkluzywność badanej metody. Biorąc pod uwagę argumenty opisane szczegółowo w części 4., każdy wynik testu Granger-przyczynowości można interpretować na różne sposoby.

\section{Popularność metody}

Pomimo formułowanych zastrzeżeń, definicję przyczynowości w sensie Grangera zastosowano do roku $2014 \mathrm{w}$ ponad 45 tysiącach badań zindeksowanych przez najpopularniejszą wyszukiwarkę artykułów naukowych na świecie [Jascó, 2005]. Popularność omawianej metody wciąż rośnie. Testy Granger-przyczynowości użyto także poza dziedzina, dla której zostały zaproponowane (tj. ekonometria) i są wykorzystywane m.in. przez: neurobiologów, epidemiologów, socjologów, finansistów itd.

Przyczyn rosnącej popularności przyczynowości w sensie Grangera można doszukiwać się w rozwoju dziedzin nauki, w których bezpośrednia ingerencja w badane zjawisko 
jest niemożliwa, co skłania naukowców do zastosowania metod empirycznego poznania zależności przyczynowych $\mathrm{z}$ danych obserwacyjnych, bez odwoływania się do eksperymentu. Innym wytłumaczeniem jest coraz większa łatwość zastosowania metody dzięki popularności pakietów komputerowych, zawierających wbudowane funkcje testowania Granger-przyczynowości [Bressler, Seth, 2010].

Bez względu na jej źródła, popularność przyczynowości w sensie Grangera skłania do rozważenia użyteczności tej metody, biorąc pod uwagę błędne wnioski, do jakich może prowadzić jej zastosowanie. Czy wykrycie Granger-przyczynowości umożliwia rozwój nauki, czy jest wyłącznie powodem błędnego opisu rzeczywistości, tj. utożsamiania przypadkowych korelacji z zależnościami przyczynowymi i niedostrzegania rzeczywistych związków i mechanizmów przyczynowych?

\section{Pojęcie przyczynowości w sensie Grangera}

Filozofowie interesowali się natura przyczynowości tak długo, jak istnieje filozofia [Beebee, 2009, s. 21], mimo to przyczynowość wciąż nie doczekała się powszechnie akceptowanej definicji [Granger, 1980]. Tymczasem twórcy każdej z nich przekonuja, że właśnie ich definicja charakteryzuje się informatywnością [Cartwright, 2006]. Jednocześnie warto zauważyć, że już od początku istnienia ekonomii zajmowano się badaniem zjawisk gospodarczych w kontekście przyczynowym, o czym świadczy tytuł dzieła Smitha [Smith, 1776], który bezpośrednio wskazywał na badanie przyczyn jako cel swojej pracy. Innymi ekonomistami okresu klasycznego, zaangażowanymi w zagadnienie przyczynowości, byli Ricardo i Mill [Chu i in., 2004].

Jednak to nie teorie przyczynowości zaproponowane przez ekonomistów zainspirowały Grangera do opracowania testu statystycznego mającego za zadanie określenie występowania i kierunku zależności przyczynowej pomiędzy zmiennymi stochastycznymi, lecz filozof David Hume [Hoover, 2001]. Natomiast podkreślał on, że ludzkie zmysły nie pozwalaja dostrzegać zależności przyczynowych, co skłoniło go do przyjęcia stanowiska redukcjonistycznego [Hume, 1739]. Ten brytyjski filozof motywował swój punkt widzenia, argumentując, iż obserwator na raz może dostrzegać tylko jedno zjawisko, co implikuje, że związek pomiędzy przyczyną i skutkiem, który łączy dwa momenty continumm czasowego, jest niedostrzegalny. W związku z powyższym, Hume stał na stanowisku, że zjawisko, by mogło nosić nazwę przyczynowego, musi spełniać dwa warunki:

- przyczyna poprzedza skutek;

- $\quad$ przyczyna zawiera informacje o skutku, które nie są dostępne w szerokiej grupie innych zmiennych [Granger, 2012].

Pierwszą kwantyfikowalną definicję przyczynowości przedstawił odwołując się do drugiego punktu zaproponowanego przez Hume'a i Wienera [Hume, Wiener, 1956]: dla dwóch jednocześnie mierzonych sygnałów, jeśli możemy lepiej przewidzieć pierwszy sygnał przy użyciu przeszłych informacji z drugiego sygnału niż przy użyciu danych nie zawierających tej informacji, możemy nazwać ten sygnał przyczyną dla pierwszego sygnału. 


\subsection{Aksjomaty}

Definicja przyczynowości zaproponowana przez Grangera opiera się na trzech założeniach:

1. Przeszłość i teraźniejszość mogą powodować przyszłość, ale przyszłość nie może powodować przeszłości;

2. $\quad \Omega_{\mathrm{t}}$ (całkowita wiedza dostępna we wszechświecie w chwili t) nie zawiera zbędnej informacji, tzn. jeśli jakaś zmienna $Z_{t}$ jest funkcjonalnie powiązana $z$ jedną lub wieloma innymi zmiennymi $w$ deterministyczny sposób, to $Z_{t}$ powinna być wyłączona $z$ ' $\Omega_{\mathrm{t}}{ }^{3}$;

3. Wszystkie zależności przyczynowe mają stały kierunek bez względu na upływ czasu [Granger, 1980]

Autor testu Granger-przyczynowości przyznał w swoim wykładzie z okazji przyznania przez Sveriges Riksbank (Szwedzki Bank Narodowy) Nagrody Pamięci Alfreda Nobla w Naukach Ekonomicznych, że dwa pierwsze aksjomaty, na których jest zbudowana jego teoria, inspirowane sa poglądami Hume'a [Dafour, Taamouti, 2010]. Trzeci aksjomat jest odpowiedzią na zarzut przedwczesnego nazywania korelacji zależnościa przyczynowa, który - dzięki swej popularności - doczekał się wpisu do encyklopedii Wikipedia pod hasłem Correlation does not imply causation [Stern, 2011]. Granger [Granger, 1980], posługując się przykładem modelu z trzema szeregami czasowymi (liczbą pacjentów przyjmowanych do szpitala w dniu t; liczbą pacjentów wypisywanych w dniu t; wielkością sprzedaży lodów w tym samym mieście w dniu t) uzasadnia trzeci aksjomat, wskazując, iż jedynie zależności, które trwają w czasie, mogą być podejrzewane o bycie przyczynowymi. Mimo możliwości zaobserwowania chwilowej korelacji pomiędzy liczbą pacjentów opuszczających szpital oraz sprzedażą lodów, nie są one powiązane strukturalnie i ich korelacja prawdopodobnie nie będzie istotna statystycznie, gdy weźmie się pod uwagę odpowiednio długi okres.

$\mathrm{Na}$ podstawie powyższych aksjomatów Granger sformułował definicję ogólną (ang. general definition):

$$
\begin{gathered}
Y_{\mathrm{t}} \text { powoduje } \mathrm{X}_{\mathrm{t}+1}, \text { jeśli: } \\
P\left(X_{t+1} \in A \mid \Omega_{t}\right) \neq P\left(X_{t+1} \in A \mid \Omega_{t}-Y_{t}\right) \text { dla pewnego A, } \\
X_{t} ; Y_{t}-\text { zmienne podejrzewane o zależność przyczynowa, } \\
\Omega_{t}-\text { cała wiedza dostępna we wszechświecie w chwili t. }
\end{gathered}
$$

Biorąc pod uwagę ograniczenie związane $\mathrm{z}$ liczbą stopni swobody w odniesieniu do całej dostępnej wiedzy w czasie testowania istnienia Granger-przyczynowości pomiędzy skończonymi szeregami czasowymi, zastosowanie powyżej przytoczonej definicji jest niemożliwe. Rozważając aplikowalność definicji w badaniach empirycz-

\footnotetext{
$2 \mathrm{~W}$ thumaczeniu angielskim: The past and present may cause the future, but the future cannot cause the past.

${ }^{3} \mathrm{~W}$ tłumaczeniu angielskim: $\Omega_{n}$ contains no redundant information, so that if some variable $Z_{n}$ is functionally related to one or more other variables, in a deterministic fashion, then $Z_{n}$ should be excluded from ' $\Omega_{n}$.

${ }^{4} \mathrm{~W}$ tłumaczeniu angielskim: All causal relationships remain constant in direction throughout time.
} 
nych, Eichler [Eichler, 2007] stwierdził: ważne jest posiadanie operacyjnej definiciji praycsynowości, która pozwala dostryegać relacje praycsyna-efekt również z. badan obserwacyjnych ${ }^{5}$.

Granger [Granger, 1969], by umożliwić praktyczne zastosowanie zaproponowanej definicji przyczynowości, zredefiniował ${ }^{2}{ }_{t}$, które ma być rozumiane jako zbiór wartościowych informacji. Zgodnie z powyższą definicja, zmienna $Y$ jest przyczyną zmiennej $\mathrm{X}$, jeśli zawiera oryginalne, dodatkowe informacje, które pomagaja przewidywać wartości drugiej zmiennej.

Rok po przedstawieniu przez Grangera metody testowania zależności przyczynowych w szeregów czasowych, Suppes [Suppes, 1970] rozwiną probabilistyczną teorię przyczynowości, tworząc, m.in. definicję: zdarzenie A powoduje prima facie zdarzenie B jeśli warunkowe prawdopodobieństwo B (pray znamym A) jest wieksze niž tylko B $i$ zdarzenie A pojawia sie po zdarzeniu $B^{6}$ :

$$
P(B \mid A)>P(B) .
$$

Zgodnie z pomysłem Suppesa, Granger [Granger, 1980] zaproponował definicję przyczynowości prima facie, która wykorzystuje jedynie dwa szeregi czasowe, nie odwołując się do zbioru wszystkich lub wartościowych informacji (' $\left.\Omega_{n}\right)$. Zmienna Y prima facie wpływa na zmienna $X$, jeśli:

$$
\begin{gathered}
P\left(X_{t+1} \in A \mid X, Y\right) \neq P\left(X_{t+1} \in A \mid X\right) \quad \text { dla pewnego A, (3) } \\
\mathrm{X} \text { - historia szeregu czasowego } \mathrm{X}, \\
\mathrm{X}, \mathrm{Y} \text { - historie szeregów czasowych } \mathrm{X} \text { i } \mathrm{Y}, \\
X_{t+1} \text { - wartość zmiennej w momencie } \mathrm{t}+1 .
\end{gathered}
$$

Brak związku pomiędzy stopniem podobieństwa Granger-przyczynowości i przyczynowości sensu largo a użytecznością tej metody dla rozwoju nauki dobrze oddaje argumentacja Grangera: Zwykklych stów, takich jak jabtko i strach, wisywa sie, bedac rozumianym przez wiekeszośc ludzi, dla których oznaczaja one mniej wiecej to samo. Podobnie, zaczynajac wylktad można, by być zrozumialym, zdefiniować pojecie wariancii lub oznaczenie 'cos x'. Ponadto, [pisał Granger - przypis autora], definiujac ' $x$ ' $w$ sposób, który zayykle oznaczamy 'cos $x$ ' nie zyska sie popularności, jednak nie jest to logicznym błedem [Granger, 1980]. Zgadzając się z przytoczoną powyżej argumentacją, należy zastanowić się, czy testy Granger-przyczynowości są informatywne, biorąc pod uwagę możliwe błędne wnioski na temat zależności pomiędzy zmiennymi.

Powyższe, skrótowe omówienie myśli, jakie zainspirowały Grangera do sformułowania pojęcia przyczynowości, miało na celu pokazanie, iż pomysł Grangera posiada legitymację filozoficzną do bycia nazwanym przyczynowością, mimo pewnych głosów sprzeciwu. Dla przykładu, Leamer [Leamer, 1985] argumentował przeciwko powyższej tezie i postulował termin poprzedzania (ang: precedence). Filozoficzne inspiracje Grangera zostały szerzej opisane przez Triacca [Triacca, 2007]. Z drugiej strony, omówiona w dalszej części niekonkluzywność wniosków wyciaganych na podstawie wy-

${ }^{5} \mathrm{~W}$ thumaczeniu angielskim: It is therefore important to have an operational definition of causality that allows inference about cause-effect relationships also from observational studies.

${ }^{6} \mathrm{~W}$ thumaczeniu angielskim: An event $A$ causes prima facie an event $B$ if the conditional probability of $B$ given $A$ is greater that $B$ alone, and $A$ occurs before $B$. 
ników testu Granger-przyczynowości może wskazywać, iż krytyka odwołująca się do innych definicji może stanowić przyczynek do dalszych badań problemu.

\section{Problemy związane z zastosowaniem testu przyczynowości w sensie Grangera}

Pomimo wciąż rosnącej popularności zastosowania testów Granger-przyczynowości w badaniach empirycznych, nie jest to metoda wolna od wad dotycząca stwierdzenia, czy zależność przyczyna-skutek istnieje w danych obserwacyjnych. W dotychczasowej literaturze przedmiotu, poświęconej pułapkom związanym z tą metoda, brakuje rozważań na temat informatywności tej metody. Dlatego istotne wydaje się przedstawienie wszystkich obszarów zawodności wskazywanych we wcześniejszych badaniach oraz rozważenie, czy na podstawie wyniku testu Granger-przyczynowości można prawomocnie wnioskować na temat zależności pomiędzy zmiennymi.

\subsection{Metody inferencji zależności przyczynowej}

Opracowano wiele testów statystycznych do stwierdzenia występowania Grangerprzyczynowości. Najpopularniejszymi są: bezpośredni test Grangera [Granger, 1969], który opiera się na estymacji modelu liniowego, gdzie zmienną objaśnianą jest Y, a regresorami opóźnione wartości: Y i X oraz test Simsa [Sims, 1972], który opiera się na estymacji dwóch równań objaśniających: $\mathrm{X}_{\mathrm{t}}$ oraz $\mathrm{Y}_{\mathrm{t}}$. W celu oceny zależności przyczynowej należy obliczyć istotność statystyczną odpowiednich parametrów regresji, które oszacowano metodą najmniejszych kwadratów. Wybrane testy przyczynowości oraz ich zastosowanie zostało dokładniej opisane przez Osińska [Osińska, 2008, s. 74-83 i 224-229]. Geweke i in. [Geweke i in., 1983] udowadnili dedukcyjnie, że siła ośmiu wziętych pod uwagę w badaniu testów jest różna, tj. odrzucają one fałszywą hipotezę o braku występowania Granger-przyczynowości z różną częstością. Podobne wyniki uzyskali Nelson i Schwert [Nelson, Schwert, 1982] oraz Geweke i in. - we wspomnianym wcześniej badaniu [Geweke i in., 1984] - na podstawie przeprowadzonych symulacji Monte Carlo. Conway i inni stwierdzili jednoznacznie: można latwo wyprodukować sprzeczne rezultaty, angażujac wiele testón przyczynowości do analizy tego samego zbioru danych ${ }^{7}$ [Conway i in., 1984].

Powyższe wyniki wskazuja, iż istnieje możliwość, że występowanie Granger-przyczynowości zostanie w dwóch różnych badaniach tego samego zjawiska (przeprowadzonych na podstawie tych samych danych) przyjęte i odrzucone wyłącznie z powodu wyboru innych metod przez autorów, co jest niezgodne z trzecim aksjomatem (o stałości w czasie) definicji zaproponowanej przez Grangera.

Ponadto, ze względu na brak możliwości użycia w regresji całej historii zmiennych: X i Y, należy arbitralnie wybrać długość opóźnień szeregów czasowych: X i Y, dla

\footnotetext{
${ }^{7} \mathrm{~W}$ tłumaczeniu angielskim: (...) one could easly produce conflicting conclusions by employing a battery of causality tests on the same data sets.
} 
których zostaną oszacowane współczynniki regresji. Ashrafulla i in. [Ashrafulla i in., 2012] wskazują na możliwość zastosowania wiedzy o modelowanym procesie (ang. background knowledge). Innym rozwiązaniem jest oparcie wyboru na funkcji autokorelacji (ACF) lub kryterium informacyjnym Akaike'a (AIC), [Liu, Bahadori, 2012].

Arbitralność powyższej decyzji powoduje, że nawet wykorzystanie tego samego testu przyczynowości może prowadzić do uzyskania przeciwnych wyników, co zaobserwował Slaugh [Slaugh, 1981], porównując wyniki badań empirycznych na temat zależności między agregatami pieniężnymi (ang. money) i dochodem (ang. income) [Conway $\mathrm{i}$ in., 1984].

Podczas formułowania wniosków na podstawie wyników testów przyczynowości w sensie Grangera należy pamiętać, iż najpopularniejsze testy (m.in. ogólny test Grangerprzyczynowości, test Simsa oraz zmodyfikowany test Simsa) rozstrzygaja wyłącznie o istnieniu zależności liniowej. Oznacza to, że negatywny wynik testu, tj. odrzucenie hipotezy zerowej o braku zależności przyczynowej prowadzi do wniosku o istnieniu zależności, którą rozumie się pod pojęciem Granger-przyczynowości. Z drugiej strony przyjęcie hipotezy zerowej nie oznacza, że pomiędzy dwiema zmiennymi nie zachodzi zależność Granger-przyczyna - skutek, a jedynym uprawomocnionym logicznie wnioskiem jest stwierdzenie o braku liniowej zależności. Opracowano również testy badające zależności nieliniowe, jednak w ich przypadku wynik testu jest także zależny od przyjętej funkcji regresji.

\subsection{Wpływ przekształceń matematycznych szeregów czasowych na wyniki testów Granger-przyczynowości}

Ze względu na aksjomaty leżące u podstaw najpopularniejszych metod ekonometrycznych, które muszą być spełnione, by badacz mógł prawomocnie skorzystać choćby z estymacji parametrów równania klasyczną metodą najmniejszych kwadratów (KMNK), w przypadku niektórych szeregów czasowych zaleca się linearyzację danych. Dla przykładu, standardowa procedurą ekonometryczną jest logarytmowanie szeregów czasowych. Roberts i Nord [Roberts, Nord, 1985], odwołując się do danych opisujących dochód nominalny, zarobki oraz podaż pieniądza, wykazali silną zależność obserwacji Granger-przyczynowości od formy funkcyjnej modelu. Zależności przyczynowej nie zaobserwowano pomiędzy szeregami czasowymi, które przeszły transformację logarytmiczna, podczas gdy surowe dane wykazywały istotną statystycznie Granger-przyczynowość. Brassler i Seth [Brassler, Seth, 2010], mimo powyższej argumentacji, uznali, że linearyzacja stanowi dobre przybliżenie w zastosowaniach Granger-przyczynowości w neurologii.

Innym problemem, z którym borykają się naukowcy stosujący metody ekonometryczne do rzeczywistych danych, jest niestacjonarność danych. Niestacjonarność szeregu czasowego powoduje występowanie trendu stochastycznego, czego przejawem są statystycznie istotne różnice w wartościach średnich z różnych podokresów zbioru danych. Zwykle, w przypadku budowy modelu opartego na zintegrowanej (tj. niestacjonarnej) zmiennej $\mathrm{X}$, zaleca się przekształcenie szeregu czasowego zgodnie z ponizszym wzorem: 


$$
X_{t}^{\prime}=X_{t}-X_{t-1}
$$

Mimo że powyższa, standardowa procedura poprawia jakość modelu, może negatywnie wpływać na prawdziwość wyniku testów Granger-przyczynowości. Glasure i Lee [Glasure, Lee, 1998], przeprowadzając analizę zależności przyczynowych pomiędzy PKB a zużyciem energii w Korei Południowej oraz Singapurze, wykonali testy Granger-przyczynowości zarówno dla zmiennych skointegrowanych, jak i zastosowali model korekty błędem (ang. error-correction moded). Autorzy uzyskali sprzeczne wyniki; test przyczynowości dla modelu korekty błędem wykazał silną zależność przyczynowa w obu kierunkach; w pierwszym przypadku nie uzyskano istotnej statystycznie Granger-przyczynowości (w żadnym kierunku) dla danych z Korei. Ponadto, autorzy zauważyli, iż ich wyniki różnią się od opisanych przez Yu i Choi [Yu, Choi, 1985]. Możliwa przyczyną jest zastosowanie przez nich różnicowanych (zgodnie z powyższym równaniem) danych, choć Glasure i Lee [1998] wskazali na inny okres badania jako przyczynę.

Lee $\mathrm{i}$ inni [Lee $\mathrm{i}$ in., 2002] podali w wattpliwość w obiektywność testów przyczynowości w sensie Grangera w przypadku skointegrowanych zmiennych, wskazując, że wyniki mogą stronniczo wprowadzać w błąd, często odrzucając prawdziwą hipotezę zerowa. Dokładniejszą dyskusję oraz porównanie wyników uzyskanych za pomocą różnych testów Granger-przyczynowości można znaleźć w pracy Hackera i Abdulnassera [Hacker, Abdulnasser, 2006]. Powyższe wyniki nie są szeroko znane wśród ekonometryków. Dla przykładu, Osińska dopuściła wykorzystanie testów Granger-przyczynowości do analizy niestacjonarnych szeregów czasowych, gdy niestacjonarnośc mo że być usunieta poprzez uprowadzenie sketadnikón deterministycznych (trend, sezonowośc) lub transformage danych, (...) jak rónmiez w stosunku do procesón skointegrowanych. W innych formach niestacjonarności takie podejście może być nieodpowiednie lub wtaścine tylloo w pryybliżenin [Osińska, 2008, s. 75].

Bardziej zaawansowaną matematycznie droga do usunięcia niestacjonarności w danych, która jest stosowana w przypadku danych charakteryzujących się sezonowościa, są modele klasy ARIMA (ang. Autoregressive Integrated Moving Average). Celem ich wykorzystania jest przewidywanie przyszłych wartości szeregu czasowego lub lepsze zrozumienie elementów składowych (AR, I, MA - autoregresja, integracja, średnia krocząca) wpływających na wartość zmiennej. Precyzyjniejszy ich opis zawarł Mills [Mills, 1990].

W latach siedemdziesiątych, niedługo po zaproponowaniu przez Grangera definicji przyczynowości, uważano, iż transformacje nieliniowe (np. wspomniana wyżej logarytmizacja lub przetworzenie szeregu czasowego modelem ARIMA) zachowują zależności przyczynowe [Conway i in., 1984]. W związku z wynikami badań nad zależnościami pomiędzy stopa wzrostu gospodarczego, podaża pieniądza i stopa inflacji, uzyskanymi przez m.in.: Feige i McGee [Feige, McGee, 1976], które przeczyły wcześniejszym teoriom i dotychczasowej literaturze przedmiotu, Schwert [Schwert, 1979] przeprowadził analizę trzech kontrprzykładów - danych dotyczących innowacji o różnym stopniu przekształcenia modelem klasy ARIMA, wykazując, iż testy przyczynowości zbyt często akceptowały hipotezę zerową. Do odwrotnych wniosków na podstawie symulacji Monte Carlo doszli Lee i inni [Lee i in., 2002], obserwując zbyt częste 
odrzucanie hipotezy zerowej o braku Granger-przyczynowości pomiędzy dwoma niezależnymi procesami ARIMA $(1,1,0)$.

Otrzymane wnioski skłoniły Schwerta [Schwert, 1979] do stwierdzenia: powinno

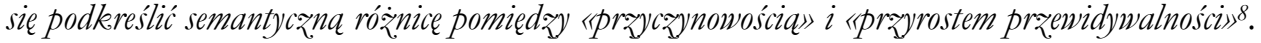
Odpowiedź na pytanie, czy mniej drastyczne przekształcenia, np. zastosowanie wyłącznie autoregresyjnej (AR) części modelu nie zmienia zależności przyczynowej pomiędzy szeregami czasowymi, wymaga dalszych badań.

Szeregi czasowe tworzą zbiory wartości zmiennych ekonomicznych, które są zwykle publikowane w pewnych odstępach czasu. Można udowodnić [McCrorie, Chambers, 2006], że jeśli kwartalne obserwacje pewnego procesu są opisane przez model VAR (vector autoregresive), to będą one tożsame z modelem VARMA (o średniej kroczącej o długości 3 okresów) obserwacji danych miesięcznych. Oznacza to, że wpływ agregacji zmiennej po czasie może niekorzystnie wpłynąć na zależności przyczynowe.

\subsection{Częstość próbkowania}

McCrorie i Chambers [McCrorie, Chambers, 2006] przeprowadzili interesujące badanie, testując przyczynowość w sensie Grangera w trzech wariantach szeregów czasowych, różniących się od siebie stopniem agregacji po czasie (ang. temporal aggregation). Na podstawie studium przypadku, które dotyczyło zależności przyczynowej pomiędzy pieniądzem i dochodami (ang. money-income causality), stwierdzili, że rzadko próbkowane procesy ekonomiczne wykażą dwukierunkową Granger-przyczynowość, pomimo istnienia zależności jednokierunkowej w przypadku prowadzenia częstszych obserwacji. Autorzy podkreślili, że uzyskanie wyniku dwukierunkowej przyczynowości w sensie Grangera nie rozstrzyga czy taka zależność rzeczywiście istnieje pomiędzy analizowanymi szeregami czasowymi.

Harvey i Stock [Harvey, Stock, 1989] przedstawili dowody na powstawanie błędnych zależności przyczynowych, badając podaż pieniądza i dochód. Test Granger-przyczynowości przyjmuje hipotezę zerową (o nieistotności statystycznej parametrów) w przypadku posłużenia się ciagłym czasem w modelu. Posłużenie się agregacją czasową i modelowanie danych kwartalnych powoduje zmianę wyniku testu, który wykazuje silną zależność przyczynową pomiędzy podażą pieniądza i dochodem. Autorzy wnioskowali na podstawie badań, że wynik testu Granger-przyczynowości jest zależny od interwału czasowego szeregu użytego w modelu w stosunku do zmiennych przepływowych (ang. flow variables), takich jak: dzienna lub miesięczna wartość obrotu na rynku, obserwowanych jako wartość zagregowana dla pewnego okresu. Ponadto, w artykule przypuszcza się, że taka zależność może zachodzić również w odniesieniu do zmiennych obserwowanych w punkcie czasu (ang. stock variables). Przykładem takiej zmiennej jest cena aktywa w chwili $t$.

\footnotetext{
${ }^{8} \mathrm{~W}$ thumaczeniu angielskim: (...) semantic distinction between 'causality' and 'incremental predictability' should be emphasized.
} 
Powyższe wyniki zostały potwierdzone przez Renault i inni [Renault i in., 1998] na podstawie testów przyczynowości pomiędzy frankiem szwajcarskim i marką niemiecką w modelach o ciagłym i nieciagłym czasie. McCrorie i Chambers [McCrorie, Chambers, 2006] podsumowali te rezultaty, uznając, że budowa modeli opartych na danych próbkowanych rzadziej niż następują rzeczywiste zmiany wartości zmiennej może prowadzić do złej interpretacji zależności między danymi. Przykładem takiego sposobu modelowania jest wykorzystanie danych dziennych w przypadku modelowania rynku giełdowego.

\subsection{Hipoteza racjonalnych oczekiwań a relacja przyczyna-skutek}

Przewidywania czynione przez ludzi moga przyczyniać się do wyciąania błędnych wniosków z wyników testów Granger-przyczynowości. Jeżeli oczekiwania podmiotów ekonomicznych są racjonalne, to nie istnieje możliwość lepszej predykcji zmiennej na podstawie tego samego zbioru danych. Innymi słowy, w czasie prognozowania nie jest popełniany systematyczny błąd. Dla przykładu, gdyby przedsiębiorstwa umiały przewidywać inflację (I) zgodnie z powyższym schematem i dokonywałyby zamówień (X), których wielkość jest zależna od przyszłego wzrostu cen oraz kosztów składowania zapasów, można byłoby oczekiwać zależności przyczynowej, której kierunek byłby niezgodny z upływem czasu:

$$
I_{t+1} \underset{\text { Granger powoduje }}{\longrightarrow} X_{t} .
$$

Taka zależność byłaby niezgodna z pierwszym założeniem leżącym u podstaw przyczynowości w sensie Grangera (por. 3.1. Aksjomaty, powyżej), które mówi, że przyszłość nie może powodować przeszłości. Czy jest możliwe, by przyszłe wartości jednej zmiennej powodowały aktualną wielkość innej? Opinie są podzielone: Noble [Noble, 1982] wskazał na uzyskanie istotnej statystycznie zależności, gdzie stopa bezrobocia powoduje w sensie Grangera zagregowane wydatki nominalne, co jest wynikiem przeciwnym do przewidywań formułowanych na podstawie teorii ekonomicznej [Nelson, 1981].

W celu obrony tradycyjnego pojmowania przyczynowości, zgodnie z którym przeszłość nie może być powodowana przez przyszłość, Noble [Noble, 1982] testował hipotezę racjonalnych oczekiwań na podstawie analizy wyników ankiety na temat przewidywanego poziomu inflacji z Survey Research Center at the University of Michigan. Uzyskane wyniki świadczą o nieprawdziwości hipotezy racjonalnych oczekiwań, jednak warto zwrócić uwagę na pewne nieścisłości w przeprowadzonym badaniu, które mogły doprowadzić do błędnych wniosków. Po pierwsze, w okresie którego dotyczyło badanie, kilkukrotnie zmieniano metodologię, tj. częstotliwość przeprowadzania ankiet oraz sposób zadawania pytań. Po drugie, ankieterzy nie pytali o przewidywaną wysokość inflacji. Na przykład, w okresie 1948-1961 pytano o kierunek zmian poziomu cen 
oraz jego siłę?. Na podstawie odpowiedzi na takie pytania autor badania Granger Causality and Expectational Rationality estymował wartość przewidywanej inflacji, przypisując arbitralnie wartości liczbowe do udzielonych odpowiedzi; przykładowo odpowiedź „inflacja wzrośnie niewiele” była uznana jako predykcja wzrostu poziomu cen o $2 \%$.

Taka metodologia może łatwo prowadzić do błędów ze względu na nieścisłość pytania. Ponadto, można bronić hipotezy racjonalnych oczekiwań w sposób podobny do argumentu naukowców wspierających hipotezę rynków efektywnych. Do jej prawdziwości wystarczającym warunkiem jest, by wyłącznie niektórzy uczestnicy rynku właściwie przewidywali przyszłość, wtedy i tylko wtedy, gdy dysponują oni środkami na tyle dużymi, by wpłynać na ceny.

Hipoteza racjonalnych oczekiwań, jeśli jest prawdziwa w przypadku badanych zmiennych ekonomicznych, może stanowić argument przemawiajacy za odwrotną rzeczywistą zależnością przyczynową w stosunku do wskazanej przez test Granger-przyczynowości.

\subsection{Zmienne ukryte}

Poza opisanymi wyżej błędami związanymi bezpośrednio z metodą testowania przyczynowości w sensie Grangera, niewłaściwe wnioski o zależności pomiędzy zmiennymi mogą wynikać z błędnej specyfikacji modelu. Metody inferowania zależności przyczynowych z danych sa najczęściej stosowane w sytuacji, gdy nie dysponuje się teorią wyjaśniającą badane zjawisko. Może to prowadzić do błędnej specyfikacji modelu przyczynowego, gdy test Granger-przyczynowości jest aplikowany do niewłaściwej pary szeregów czasowych. Wyróżnia się dwa takie przypadki: błąd wspólnej przyczyny oraz przyczynowość pośrednia (ang. indirect causality).

Jedną z najczęściej wskazywanych przyczyn prowadzących do błędnej interpretacji pozytywnych wyników testowania Granger-przyczynowości pomiędzy dwiema zmiennymi jest istnienie szeregu czasowego, który determinuje: $\mathrm{X}$ i Y, tj. szeregi, pomiędzy którymi zaobserwowano związek [Chu i in., 2004]. Błąd wspólnej przyczyny (ang. common cause fallacy) można zilustrować grafem przedstawionym na rysunku 1.

Dobrą ilustracja grafu jest przykład [Woodward, 2007] badania zależności pomiędzy rodzajem edukacji (publiczna/prywatna) a wynikami egzaminów. Jeśli nie bierze się pod uwagę poziomu dochodów rodziców ucznia, a jedynie typ szkoły, można dojść do błędnych wniosków, że to wybór publicznej lub prywatnej edukacji jest przyczyną lepszych wyników.

\footnotetext{
${ }^{9} \mathrm{~W}$ thumaczeniu angielskim: What do you expect prices of haousehold items and clothing will do during the next year or so-stay where they are, go up, or go down? Do you think that prices will be a lot higher (lower) or only a little higher (lower) nex year?
} 
RYSUNEK 1. Zależności między zmiennymi prowadzące do błędu wspólnej przyczyny

Z

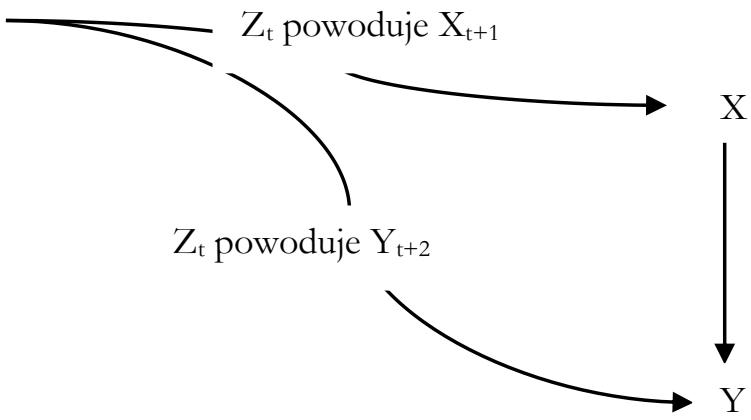

$\mathrm{X}_{\mathrm{t}+1}$ Granger-powoduje (dla obserwatora) $\mathrm{Y}_{\mathrm{t}+2}$

Źródło: opracowanie własne.

Glymour i Sprites [Glymour, Sprites, 1988] wskazali na istnienie testów ekonometrycznych wykrywających istnienie ukrytych zmiennych (ang. latent variables), jednak ich zastosowanie wydaje się wątpliwe, zwłaszcza w przypadku testowania Granger-przyczynowości prima facie, ze względu na brak odpowiedniej specyfikacji modelu. Oznacza to, że jedynym sposobem uniknięcia błędu wspólnej przyczyny jest właściwe zrozumienie mechanizmów rządzących badanym zjawiskiem i odpowiednie dobranie szeregów czasowych, pomiędzy którymi przeprowadza się test Granger-przyczynowości.

Sugestią istnienia wspólnej przyczyny badanych szeregów czasowych może być wynik testu Granger-przyczynowości, który objaśnia istnienie dwukierunkowej zależności, tj. wyniki obu testów ukazują zależność przyczynową:

$$
\begin{aligned}
& X \rightarrow Y, \\
& Y \rightarrow X .
\end{aligned}
$$

Badanie sztucznie generowanych szeregów czasowych zależnych od trzeciej zmiennej wykazało, że w przypadku, określanym nazwą wspólnej przyczyny, bardziej prawdopodobne jest odkrycie dwukierunkowej zależności niż błędnej, jednokierunkowej zależności przyczynowej [Sims, Sargent, 1977]. Warto zauważyć, że powyższe wyniki nie są znane niektórym naukowcom stosującym testy Granger-przyczynowości, którzy w świetle wyników osiągniętych przez Simsa błędnie interpretują uzyskanie wyników odrzucających hipotezę zerową (o braku Granger-przyczynowości) w obu przypadkach. Przykładem są badania Madrak-Grochowskiej i Żurek [Madrak-Grochowska, Żurek, 2011].

Drugim przypadkiem, kiedy badacz może mieć do czynienia ze zmienną ukrytą jest tzw. przyczynowość pośrednia (ang. indirect causality). W przeciwieństwie do wcześniej omawianej sytuacji, gdy wynik testu Granger-przyczynowości wykazuje istnienie zależności, która nie jest prawdziwa, zjawisko przyczynowości pośredniej może powodować błąd drugiego rodzaju. Pomimo propozycji uogólnienia pojęcia przyczynowości w sensie Grangera na więcej okresów [Dufour, Taamouti 2010], standardowe testy 
wskazują wyłącznie zależność w horyzoncie czasowym, równym jeden. Oznacza to, że zarówno w przypadku wpływu opóźnionego:

$$
X_{t} \rightarrow Y_{t+2}
$$

jak i wtedy, gdy istnieje szereg czasowy przenoszący informację pomiędzy dwiema zmiennymi:

$$
X_{t} \rightarrow Z_{t+1} \rightarrow Y_{t+2}
$$

standardowe testy Granger-przyczynowości nie odrzucą hipotezy zerowej, mimo istnienia zależności pomiędzy zmiennymi. Obrońcy pojęcia przyczynowości w sensie Grangera mogą bronić metody, argumentując, że w powyższym przypadku można mówić jedynie o zależności przyczynowej pomiędzy: X i Z oraz Z i Y. Nie jest to trafna uwaga. Dla przykładu, kurs walutowy $(\mathrm{X})$ wpływa na wielkość popytu $(\mathrm{Z})$, a od niej zależy PKB $(Y)$. Odwołując się do manipulacjonistycznej teorii przyczynowości, można stwierdzić, iż w powyższym eksperymencie myślowym zmiany kursu walutowego (wpływając na terms-of-trade) powoduja zmiany PKB, tj. X powoduje $\mathrm{Y}$, co nie zostanie wykazane przez wynik testu Granger-przyczynowości.

\section{Przyczynowość a egzogeniczność i możliwość wpływania na system ekonomiczny}

Ważnym powodem poszukiwań relacji przyczynowych jest chęć kontroli systemu ekonomicznego. By odpowiedzieć na pytanie, czy relacja odkryta testem Grangerprzyczynowości utrzyma się, pomimo podejmowanych interwencji rynkowych, należy rozważyć powiązania pomiędzy przyczynowością w sensie Grangera a egzogenicznością (tj. niezależnością od wartości innych zmiennych w modelu) zmiennej w strukturalnym podejściu do ekonometrii.

Wybór zmiennych egzogenicznych modelu umożliwia wskazanie tych zmiennych, na które oddziałując, wpływa się na system (np. ekonomiczny). Taka analiza pozwala na określenie porządku przyczynowego w analizowanym zjawisku [LeRoy, 2004]. Niestety, wyniki testów Granger-przyczynowości nie są w tym pomocne. Sargent [Sargent, 1976] oraz Cooley i LeRoy [Cooley, LeRoy, 1985] wykazali brak zwiazku pomiędzy istnieniem przyczynowości w sensie Grangera oraz możliwościa interwencji, którą umożliwia niezmienność strukturalna mechanizmu lub modelu. Zachodzi jedynie jednokierunkowy związek pomiędzy przyczynowością w sensie Grangera i ścisłą egzogenicznością. Wykrycie istotnej statystycznie Granger-przyczynowości świadczy o braku ścisłej egzogeniczności. Oznacza to, że skutek nie może być zmienną ściśle egzogeniczna. Odmienny wynik testu, tj. przyjęcie hipotezy zerowej o braku Grangerprzyczynowości nie implikuje egzogeniczności pieniądza. Cooley i LeRoy [Cooley, LeRoy, 1985] stwierdzili na podstawie przeglądu badań, że naukowcy często wyciągaja nieuprawnione wnioski w odniesieniu do egzogeniczności zmiennych. 


\section{Podsumowanie}

Odrzucenie hipotezy zerowej o braku zależności Granger-przyczynowej pomiędzy dwoma szeregami czasowymi nie pozwala prawomocnie przypuszczać, że manipulacja Granger-skutkiem przy użyciu Granger-przyczyny jest możliwa [Sargent, 1978; Cooley, LeRoy, 1985]. Warto podkreślić, że jest to druga, najczęstsza motywacja do badań przyczynowych, po poznawczej. Narzędzia służące do odkrywania zależności przyczynowych na podstawie szeregów czasowych są przede wszystkim potrzebne i używane do analizy procesów, których mechanizmy pozostają nieznane, gdyż w przeciwnym przypadku, w celu poznania co jest przyczyna, a co skutkiem, można byłoby odwołać się do teorii tłumaczacej zjawisko. Jakich pewnych informacji dostarcza wynik testu przyczynowości w sensie Grangera, kiedy nie dysponuje się wiedzą o mechanizmie łączącym dwie zmienne?

Testując Granger-przyczynowość, można uzyskać trzy różne wyniki: sfalsyfikować hipotezę zerową w jednym z testów, uzyskać dwukierunkową zależność oraz przyjąc hipotezę o braku Granger-przyczynowości. Biorąc pod uwagę omówione niedostatki badanej metody, żaden z wyników nie pozwala na wyciagnięcie pewnych wniosków o istnieniu Granger-przyczynowości. Podsumowanie możliwości interpretowania wyników wraz ze wskazaniem przyczyn prowadzących do błędów zostało zamieszczone w tabeli 1 .

W pierwszym przypadku, kiedy badacz uzyska wynik testu interpretowany jako obecność jednokierunkowej zależności (przyjmijmy X Granger-powoduje Y), istnieją cztery możliwe rzeczywiste zależności:

1. Wynik testu może być prawdziwy, ti. zdanie X Granger-powoduje Y odzwierciedla rzeczywistość;

2. Badana zależność ma odwrotny kierunek. Y Granger-powoduje X, lecz w związku z racjonalnymi oczekiwaniami aktorów ekonomicznych jest obserwowany odwrotny kierunek zależności [Noble, 1982];

3. W przypadku, gdy szereg czasowy jest za rzadko próbkowany, taki wynik może oznaczać przyczynowość natychmiastową [McCrorie, Chambers, 2006];

4. Badacz może również sfalsyfikować hipotezę zerową w sytuacji braku takiej zależności z powodu: nieliniowości szeregów czasowych [Roberts, Nord, 1985], skointegrowania zmiennych [Lee i in., 2002], zbyt rzadkiego próbkowania szeregów czasowych [Harvey, Stock, 1989] oraz wspólnej przyczyny, która determinuje: X i Y [Chu i in., 2004].

W standardowych procedurach testowania Granger-przyczynowości stosuje się dwa równania regresji. Oznacza to, że można odkryć dwukierunkową zależność. Taki wynik może oznaczać:

1. Istnienie dwukierunkowej lub natychmiastowej przyczynowości w danych;

2. Brak zależności między zmiennymi: X i Y, gdy obie są Granger-powodowane przez trzecią zmienną [Sims, 1977]. 
zz_pozioma 
Przyjęcie hipotezy zerowej o braku zależności również ma wiele interpretacji:

1. Pomiędzy X i Y może zachodzić Granger-przyczynowość, która ma charakter nieliniowy. Inną przyczyną takiego błędu jest przyczynowość pośrednia [Dufour, Taamouti, 2010];

2. Niestacjonarność szeregów czasowych może powodować powyższy wynik testu w przypadku gdy zachodzi przyczynowość natychmiastowa [Glasure, Lee, 1998];

3. W trzecim przypadku niewykrycie zależności oznacza rzeczywisty brak Grangerprzyczynowości.

O ile część z przyczyn błędów można wyeliminować lub przynajmniej być ich świadomym (skointegrowanie zmiennych, nieliniowość danych), o tyle o wpływie innych czynników w niektórych przypadkach nie można posiąść wiedzy, np.: czy próbkowanie szeregu czasowego jest wystarczająco częste? Zgodnie ze znanymi autorowi badaniami nad błędami Granger-przyczynowości, jedynym prawomocnym wnioskiem jest stwierdzenie, że szeregi czasowe sa powiązane Granger-przyczynowo (choć nie można być pewnym w odniesieniu do kierunku zależności) wtedy, gdy test Grangerprzyczynowości falsyfikuje $\mathrm{H}_{0}$ w obu kierunkach, tj. X Granger-powoduje Y i Y Granger-powoduje X.

Warto zauważyć, że są także inne metody testowania obecności zależności przyczynowej między szeregami czasowymi, choć nie są one aktualnie tak popularne ani tak obszernie zbadane, jak Granger-przyczynowość. Dalszych badań wymaga odpowiedź na pytanie, czy istnieje inny, pewny sposób poznania zależności przyczynowych bez wiedzy o mechanizmie?

Granger w obronie swojej metody stwierdził, że możliwej zależności prayczynowej nie rozważa sie pomiędzy arbitralnie uybranymi grupami zmiennych, lecz tylko takimi, co do których badacz ma wczésniejsze podejrzenia, że zależność przyczynowa jest w jakimś sensie prawdopodobna ${ }^{10}$ [Granger, 1988]. Argumentacja przedstawiona w artykule potwierdza ten pogląd i rozszerza go. Wyciagnięcie prawomocnych wniosków o istnieniu i kierunku zależności przyczynowej na podstawie testu Granger-przyczynowości jest możliwe tylko wtedy, gdy posiada się wiedzę o mechanizmie łączącym dwa szeregi czasowe.

\section{Literatura}

Ashrafulla S., Haldar J., Joshi A., Leahy R. 2012 Canonical Granger causality applied to functional brain data, „Biomedical Imaging”, 9, IEEE International Symposium on IEEE.

Beebee H. 2009 Introduction, [in:] The Oxford Handbook of Causation, H. Beebee (ed.), Oxford University Press, Oxford.

${ }_{10} \mathrm{~W}$ tłumaczeniu angielskim: Possible causation is not considered for any arbitrarily selected group of variables, but only for variables for which the researcher has some prior belief that causation is, in some sense, likely. 
Bressler S. L., Seth A. K. 2010 Wiener-Granger Causality: A well established methodology, „NeuroImage", t. 58, no. 2.

Cartwright N. 2006 Where Is the Theory in Our „Theories” of Causality?, „The Journal of Philosophy", t. 103, no. 2.

Chu T., Danks D., Glymour C. 2004 Data Driven Methods for Granger Causality and Contemporaneous Causality with Non-Linear Corrections: Climate Teleconnection Mechanisms, dokument elektroniczny, tryb dostępu: [http://www.hss.cmu.edu/philosophy/ glymour/chudanksglymour2004.pdf, data wejścia: 28.12.2013].

Conway R. K., Swamy P., Yanagida J. 1984 The impossibility of causality testing, „Agricultural Economics Research", t. 36, no. 3.

Cooley Th., LeRoy S. 1985 Atheoretical Macroeconometrics. A Critique, „Journal of Monetary Economics", no. 16.

Dufour, J. M., Taamouti A. 2010 Short and long run causality measures: Theory and inference, ,Journal of Econometrics", t. 154, no. 1.

Eichler M. 2007 Causal inference from time series: What can be learned from granger causality?, „Proceedings of the 13th International Congress of Logic, Methodology and Philosophy of Science".

Feige E. L., McGee R. 1977 Monen Supply Control and Lagged Reverve Accounting, „Journal of Money, Credit and Banking", t. 9, no. 4.

Geweke J., Meese R., Dent W. 1983 Comparing alternative tests of causality in temporal systems: Analytic results and experimental evidence, ,Journal of Econometrics”, t. 21, no. 2.

Glasure Y. U., Lee A. R. 1998 Cointegration, error-correction and the relatioship between GDP and energy: The case of South Korea and Singapore, „Resource and Energy Economics”, t. 20 , no. 1 .

Glymour C., Sprites P. 1988 Latent Variables, Causal Models and Overidentifying Constraints, „Journal of Econometrics", t. 39.

Granger C. W. J. 1969 Investigating Causal Relations by Econometric Models and Crossspectral Methods, „Econometrica”, t. 37, no. 3.

Granger C. W. J. 1980 Testing for Causality. A personal Viewpoint, „Journal of Economic Dynamic and Control", t. 2, no. 4.

Granger C. W. J. 1988 Some recent developments in a concept of causality, „The Economic Record", t. 64.

Granger C. W. J. 2012 Forecasting, [in:] Philosophy of Economics, U. Maki (ed.), Elsevier, Amsterdam.

Hacker R. S., Abdulnasser H. 2006 Tests for causality between integrated variables using asymptotic and bootstrap distributions: theory and applications, „Applied Economics”, t. 38, no. 13.

Harvey A. C., Stock J. H. 1989 Estimating Integrated Higher-Order Continuous Time Autoregressions with an Application to Money-Income Causality, ,Journal of Econometrics", t. 42 .

Hoover K. D. 2001 Causality in macroeconomics, Cambridge University Press, Cambridge.

Hoover K. D. 2006 Causality in Economics and Econometrics. An Entry for the New Palgrave Dictionary of Economics, Palgrave Macmillan. 
Hume D. 1739 A treatise of human nature, „British Moralists” (1978).

Jascó P. 2005 Google Scholar: the pros and the cons, „Online Information Review”, t. 29, no. 2.

Leamer E. E. 1985 Vector autoregressions for causal inference?, „Carnegie-Rochester Conference Series on Public Policy", t. 22.

Lee H. Y., Lin K. S. Wu J. L. 2002 Pitfalls in using Granger causality tests to find an engine of growth, „Applied Economics Letters”, t. 9, no. 6.

LeRoy S. 2004 Causality in Economics, Causality: Metaphysics and method, Centre for Philosophy of Natural and Social Science, London.

Liu Y., Bahadori M. T. 2012 A Survey on Granger Causality: A computational View, University of Southern California.

Madrak-Grochowska M., Żurek M. 2011 Testowanie prayczynowości w wariancïi między wybranymi indeksami rynków akcji na świecie, „Oeconomia Copernica”, no. 4.

McCrorie J. R., Chambers M. J. 2006 Granger causality and the sampling of economic processes, ,Journal of Econometrics”, t. 132.

Mills T. C. 1990 Time Series Techniques for Economists, Cambridge University Press, Cambridge, New York.

Nelson C. R., Schwert G. W. 1982 Tests for predictive relationships between time series variables: A Monte Carlo investigation, "Journal of the American Statistical Association", t. 77 (377).

Nelson Ch. R. 1981 Adjustment Lags Versus Information Lags, Journal of Money, „Credit and Banking", luty.

Noble N. R. 1982 Causality and Expectational Rationality: Note, „Journal of Money, Credit and Banking", t. 14, no. 4, część 1.

Osińska M. 2008 Ekonometryczna analiza zależności prayczynowych, Wydawnictwo Naukowe Uniwersytetu Mikołaja Kopernika, Toruń.

Renault E., Sekkat K., Szafarz A. 1998 Testing for spurious causality in exchange rates, „Journal of Empirical Finance”, t. 6, no. 1.

Roberts D. L., Nord S. 1985 Causality tests and functional forms, „Applied Economics”, t. 17 , no. 1 .

Russo F. 2008 Methodology of Causal Modelling, [in:] Causality and Causal Modelling in the Social Sciences, F. Russo (ed.), Springer Science \& Business Media, New York.

Sargent Th. 1976 A Classical Macroeconomic Model for the United States, „Journal of Political Economy", no. 84.

Schwert W. G. 1979 Tests of causality: The message in the innovations, „Carnegie-Rochester Conference Series on Public Policy", t. 10, North-Holland.

Sims C. A. 1972 Money, Income and Causality, ,The American Economic Review”, t. 62, no. 4.

Sims Ch. A., Sargent Th. J. 1977 Business cycle modeling without pretending to have too much a priori economic theory, „Working Papers”, no. 55, Bank Rezerwy Federalnej w Minneapolis.

Slaugh J. R. 1981 Granger-Sims Causality. A Brief Survey of Its Use and Misuse, National Science Foundation. 
Smith A. 1776 An Inquiry into the Nature and Causes of the Wealth of Nations, W. Strahan and T. Cadell, London.

Stern D. 2011 From Correlation to Granger Causality, „Crawford School Research Paper", no. 13, Crawford School of Public Policy.

Sugihara G., May R., Ye H., Hsieh C., Deyle E., Fogarty M. 2012 Detecting Causality in Complex Ecosystems, „Science”, no. 338.

Suppes P. 1970 A Probabilistic Theory of Causality, „Acta Philosophica Fennica”, Fasc. XXIV, North-Holland, Amsterdam.

Triacca, U. 2007 Granger causality and contiguity between stochastic processes, „Physics Letters A", t. 362, no. 4.

Wiener N. 1956 The Theory of Prediction, „Modern Mathematics for Engineers”, McGraw-Hill, New York.

Woodward J. 2007 Causation with a Human Face, [in:] Causation, Physics and the Constitution of Reality: Russell's Republic, H. Price, R. Corry (eds.), Oxford University Press, New York.

Yu E. S. H., Choi J. 1985 The causal relationship between energy and GNP: An international comparison, „The Journal of Energy and Development”, wiosna. 